\title{
Reading hegemonic masculinities in 2 Samuel 11 in the South African contexts
}

\author{
Masenya, Madipoane \\ UNISA, Pretoria, South Africa \\ masenmj@unisa.ac.za
}

\begin{abstract}
The present essay will engage the concepts of (hegemonic) masculinities as depicted in the actions of David and Uriah in 2 Samuel 11. It is argued that although Uriah's character in the preceding text occupies a place on the hegemonic masculinities ladder, his masculinity (which is much akin to that of the majority of men in the two thirds majority world context) is subordinated to those of a more powerful man. Given the social location of the present author (and the scant research from a masculinity study perspective on his character), Uriah's character will be the focal point of attention in this essay.

From a contemporary perspective, it is argued that men in our two thirds majority world context (including African-South African men), who like Uriah, sit at the relatively lower rung of the hegemonic masculinities ladder, and subordinated to more powerful men, still have a sense of agency. Thus, such men are not completely powerless. As a point of departure, I will engage David's masculinity, basically foregrounding his abuse of power. This will be followed by an elaborate discussion on Uriah's masculinities and some sections on the agency of subordinated men. In the final analysis, concluding remarks will be made.
\end{abstract}

\section{Keywords}

Agency, Bathsheba, David, Hebrew Bible, hegemonic masculinities, patriarchy, powerless, subordinate masculinities, Uriah

\section{Introduction}

What and how a man is, becomes and should be, is constructed by his own society. Morrell could thus rightly argue: "There are as much masculinities as there are cultures, classes, times and places"(1998:607). Although masculinities are to a great extent culturally conditioned, argues 
Kopano Ratele, ideas on what it means to be a boy or a man tend to become naturalised: "Even though most girls and boys, men and women might recognise that in central ways we change as time passes and that we are unlike our grandparents, parents, friends and other people because society changes, many people seem to think of gender and sexual desires as if they are invariable."(2016:9)

Connell (2005) explains how masculinities can be subordinated as in the example of gay men who have been disqualified from the circle of "legitimate men". Masculinities can be complicit as in men who do not meet the standards of hegemonic masculinity but still benefit due to their biological sex, class and race. Marginalised men are those who have negatively been affected by factors such as class, sex, race, and ethnicity. The preceding group has no opportunity for either hegemonic or complicit masculinity (Murphy 2015:183). As it will become clear in this article though, I hold a different view from Connell's as I am persuaded that hegemonic masculinities cut across each community irrespective of people's race, ethnicity and class, among others.

The notion of hegemonic masculinities is fitting within a South African context in view of the country's history of inequities. In addition, South Africa's location on the African continent and the country's experiences of colonialism and apartheid enable us to get a glimpse on the dynamics of hegemonic masculinities on a broader scale. The following two questions form the pivot around which the present engagement will rotate: (1) If the David/Uriah (Bathsheba) narrative is read through the lens of black masculinities in South Africa, what kind of reading may emerge? (2) Do men who like, many a man in the two thirds world majority context, sit at the bottom of the hegemonic masculinities' ladder have any agency at all? In order to demonstrate varied masculinities in 2 Samuel 11, this article will discuss the following features as presented by Haddox (2016:179182): military might, bodily integrity, honour, virility, provisioning and spatiality. The preceding section will be followed by discussions on women's place within hegemonic masculinities as well as the agency of "powerless" women and men.

The first section will explore David's and Uriah's hegemonic masculinities as depicted in 2 Samuel 11. 


\section{Reading David's hegemonic masculinities in $\mathbf{2}$ Samuel 11}

One of the features which typified a real man in ancient Israel was his success in battles. In 2 Samuel 10, David is reported to have killed thousands and thousands of Aramean horsemen including Shoah, the commander of the army of Hadadezer, thus causing the "feminisation" (read-subordination) of all the other kings who were Hadadezer's servants. In 2 Samuel 10:19, we read: "When all the kings who were servants of Hadadezer saw that they had been defeated by Israel (read: David, the man), they made peace with Israel, and became subject to them. So the Arameans were afraid to help the Ammonites anymore" (emphases are the author's). Readers who are conversant with David's militant character would not regard his masculinity as being challenged by his decision to abstain from war. Unlike in the preceding chapter in which the militant character of David is depicted, the opening episode of 2 Samuel 11 reveals the direct opposite. David remained in Jerusalem (2 Sam 11:1). The reasons for such an untypical move are not mentioned (Garsiel 1993:250). Garsiel however, gives a helpful explanation on why David did not go to war including the risks involved when a king himself got directly involved in a war. The involvement of a king in battle and the success thereof, was not a value in itself. It was thus not a sign of a king's success in the exercise of his masculinity, but rather perhaps a sign of masculinity subordinated to God. He argues: "Throughout the book of Samuel, success in battle is viewed as a function of the king's conduct and not as a value in itself" (Garsiel1993:250). In the view of Clines (2013:215228) the following elements typify manhood in the David story: (1) The fighting male; (2) The persuasive male; (3) The beautiful male; (4) The bonding male; (5) The womanless male; and (6) the musical male.

Irrespective of David's choice not to go to war as is revealed in the opening of 2 Samuel 11, a reader already gets a glimpse about the notion of hegemonic masculinities. David the man in authority, sends another man (read: Joab) to war (male business) for the protection of his nation. As already noted, Clines lists the militant element as one of the components of masculinity in the world of David. There are several verses in which either David himself and/ or his warriors killed other men during wars (2013:215-228). Although the militant aspect of David's character is absent in 2 Samuel 11, the warrior element is visible in David's power to delegate other men to go and fight. 
David's militant character reveals the masculinity of a powerful male. From his actions, one gets a glimpse that a male on top of the hegemonic masculinity ladder has the power to send out his subjects, both male and female. The men who are sent out to fight would in this context, experience the subordination of their masculinities while simultaneously performing their duty as warriors. The men would revel in the pride of fighting for and protecting their people, while their wives back home (cf. Bathsheba), would, in their husbands' absences, assume the role of both "mother" and "father". Their wives would also become potential prey(s) of (other) men in the absence of their husbands.

David, the political leader who had then taken leave from a warrior life, would have a moment to take a stroll on the roof of his palace. The male gaze at an "inferior" albeit very beautiful object of gaze, would breed a disaster on a warrior's family. Although Fewell and Gunn (1993:141) engage 2 Sam 16:20-21, a text that does not precisely deal with David but focusses on his son Absalom, the essence of what is being communicated is the same. The gaze that ends up in the objectification and violation of female bodies is the male one. In 2 Sam 16:20-21, all the Israelites (read: males) were supposed to make a gaze when Absalom lay with his father's concubines! Fewell and Gunn (1993:141) reason: "So a tent is pitched on the roof of the palace - the roof from which David gazed at Bathsheba - and there Absalom enters his father's concubines 'in the sight of all Israel'” (16:22). We can infer that the hands that were strengthened were male hands, just as the gazing eyes of "all Israel" were in essence, male eyes. Boer (2011:41-52) also notes that the female body, unlike the male body, is always an object of male gaze in patriarchal contexts.

Overpowered by the lust towards an "inferior" object of gaze, one who sits at the bottom of the hegemonic masculinity ladder, David, the powerful man, exercises his power within the realm of hegemonic masculinities. Once again, he sends a subordinated man to enquire about the object of his gaze. Within the space of only three verses, the narrator gives the reader a quick reflection on what powerful, influential men are capable of doing. They are able to "control" the bodies of the properties (read: wives) of less powerful men. Such men pretty much like the powerful men within Empire in Africana history, are able to control the bodies of the females who belong to less-powerful males. For example, with reference to the 
South African context, Gqola (2013: 4) shows the detrimental effects of the power dynamics of white (male) hegemony first on black men (read: subordinated masculinities) and then from black men onto black women. Gqola further (2013:5) explains that the same ideology of supremacy which enabled White people to construct the stereotype of Black men as rapists, also created the stereotype of Black women as hypersexual and therefore impossible to rape. Perceiving Black women as impossible to rape does not make them safe against rape. It means quite the opposite: that Black women are safe to rape. Thus, when Black women make reports about being raped, they are never taken seriously. Instead, in many instances, they are accused of "inviting" it ${ }^{1}$. Hence, the criticism that cases of rape, especially against Black women, do not receive the attention which they deserve.

Although Uriah is Bathsheba's ba'al (master) and thus entitled to "lie with her" (the preceding fact will later be glimpsed from David's exhortation to Uriah in 2 Sam11:8, 10), a more powerful man will play the role of the ba'al with his loyal servant's wife. Uriah's monogamous status stands in stark contrast to David's polygamous status, the status which David shares with many traditional African rulers ${ }^{2}$. So, lust and greed can overpower even those males who sit on the top of the hegemonic masculinities ladder! Bathsheba, a woman who was the object of the king's gaze, sits at the bottom of the hegemonic masculinity ladder, or does she? In fact the construction of masculinity appears to be based on the negation of (her) femininity. Thus, Paul Leshota observes : “... in a man’s world, nothing could be as illomened, being and behaving as a woman ... For a man to be portrayed as a woman is demeaning and contemptuous. This is simply because a man can

1 Although qualitative research has shown that blaming females for "inviting" rape has not received majority consensus, there are other members of society (especially males) who blame women that they "invite" rape because of "dressing in a provocative manner" and or on women "who have a history of promiscuity". For more details on this view, see for example, Robert H. Freymeyer 1997, "Rape Myths and Religiosity", Sociological Spectrum 17(4):473; and Norma B. Gray, Gloria J. Palileo and David G. Johnson 1993, "Explaining Rape Victim Blame: A Test of Attribution Theory", Sociological Spectrum 13:377-392.

2 For example, see Tsoaledi D. Thobejane and Flora Takayindisa 2014, "An Exploration of Polygamous Marriages: A Worldview", Mediterranean Journal of Social Sciences 5/27:1063; Elijah M. Baloyi 2013, "Critical Reflections on Polygamy in the African Christian Context”, Missionalia 41(2):164-181. 
only become a man by not becoming a woman. A woman is believed to be fainthearted, powerless, emotional and weak" (2012:153).

The irony of what the powerful male figure does is that David not only fails on the virtue of self-control as one of the qualities that were supposed to typify ideal or worthy men then ${ }^{3}$; the feminine body becomes so irresistible to the male gaze, irrespective of how high on the hegemonic masculinities scale, the specific male is. David the king was conversant with the law regarding adultery (see Lev. 20:10). He was supposed to set an example of righteousness by protecting the "weak" and vulnerable (cf. Bathsheba in the present case). However, even after being told about Bathsheba's marital status, one whose husband he most probably knew, David went ahead and sent for her and "lay with her" (2 Sam 11:4).

There are different views about whether what David did with Bathsheba was rape or not. The Masoretic Text (MT) employs a terminology which does not give the readers an impression that David, the king, used force in his sexual encounter with Bathsheba, the wife of an absent husband. (Considering the language used for rape in the $\mathrm{HB}$, in which the issue of force is foregrounded, the encounter between David and Bathsheba was not rape (Abasili2011:1-15). Bailey (1990:88) also argues that on account of Bathsheba's decision to become a king's wife, she deliberately chose to take her bath on that specific location. However, Diana R. Garland and David E. Garland (2007) argue that due to the power differentials between the king (political and spiritual leader) and Bathsheba, the woman, there was no consent. I am of the opinion that when called by the king, Bathsheba may not have responded to the call without being intimidated. When she allocated a free moment to herself and her body, little did Bathsheba know that not only her free and relaxed moment would be interrupted. More importantly for this investigation, Bathsheba's body, one which, within a patriarchal space belonged to her husband, would be tampered with and violated by a man who was more powerful than her husband. The notion

3 One of the additions to the traits of biblical manhood after the publication of Clines, "David the Man" was self-control. Stephen M. Wilson remarks: "One such addition is the importance of manly self-control, which George (2010) believes to be a unifying concept in the book of Deuteronomy. An Israelite man must rein in appetites for sex (Deut. 22:24), wanton violence and plunder (Deut. 20).” (20019:27) See also, George 2010:64-82. 
of hegemonic masculinities would not only be visible in the act of David "conquering" a female body; David would also succeed in "emasculating" Uriah, a less powerful man by depositing a seed into his wife's body, on Uriah's behalf.

We as present-day readers of this male story do not have a glimpse of the length of time between David's sexual encounter with Bathsheba and her discovery that she was pregnant by adultery. Bathsheba's panic, frustration and rage made her not only to speak for the first time since our encounter with her in the story; she also does what the powerful man has been doing all along. She "sends" a word to David (2 Sam 11:5) to report her pregnancy. The foolish action of a powerful male figure will leave a mark on the body of Bathsheba, the powerless female Other. Although Bathsheba's voice is mostly muted in the present episode, as it is usually a pattern in the Hebrew Bible $(\mathrm{HB})^{4}$, we can speculate on the possible anger, guilt and shame caused by an unwanted pregnancy albeit from a more powerful man who was not her husband.

Once David received the news of the pregnancy, he acted in a foolish way. David acted like a nabal (fool) who seemed not to have known what to do and when to do it. He also seemed not to have known which word to say and at what time to say it. David did something unusual and suspicious by using his authority once more to send a word for Uriah to return home:

So, David sent word to Joab, "Send me Uriah the Hittite." And Joab sent Uriah to David. When Uriah came to him, David asked how Joab and the people fared, and how the war was going. Then David said to Uriah, "Go down to your house and wash your feet" (2 Sam11:6-8).

David had hoped that his apparent unlimited power would enable him to control another man's sexual life in order to cover up for his sin, that is, the violation of another man's wife. Little did David know that his male subordinates could under certain circumstances, defy those who are powerful than themselves. Perhaps David was unaware of Uriah's loyalty both to him, and in particular, to Israel's deity (Youngblood 1994:454). Meanwhile, Uriah, one of David's warriors, depended on David for sustenance and support, hence the total loyalty that he gave in return. 
Regina M. Swartz captures Uriah's loyalty to Israel's God succinctly: "Under the injunctions of holy war, to sleep with his own wife would be to be faithless to God; it is that fidelity, to his deity, that Uriah maintains, despite the obvious attractiveness of his wife, despite his drunkenness, and it is that fidelity to his deity that he finally dies for" (1998:346). Uriah responded to David, “The ark, Israel, and Judah dwell in makeshift shelters. My lord Joab and the officers of my lord are camping in the open field. But I may enter my house to eat, to drink, and to sleep with my wife? As you live and as your soul lives, I will not do this thing!" (2 Sam 11:11 MEV).

Could the actions of Uriah give readers some glimpse of the thoughts and actions of departed/absent husbands both in the HB and elsewhere? Could it be that absent men are not as yearning for their re-unions with their families and their wives back home? Could it be as Njabulo Ndebele (2008:21) affirms that: "Women are prisoners of the dream of romance"? When David's commitment to using Uriah as a cover-up for his adultery failed, he decided to let Uriah's departure from his family be a permanent one, not because of the conventional deaths from the military, but because of a calculated move by David, who, like many present-day political leaders, chose to be self-serving than to protect the interests of all his people. When Bathsheba heard the news of her absent husband's death, ultimately culminating into a reality of the end of her waiting period, she mourned for her husband (2 Sam 11:26). From a (South) African woman's perspective, one would not be oblivious of Bathsheba's new status of waiting for a husband who never returned. Especially during the period of apartheid in South Africa, it had been a common occurrence among many black South African women to wait for their husbands, only to be greeted by their permanent absences through death (Masenya (Ngwan'a Mphahlele) 2017: 384-402).

The focus of the present section was basically to examine how David, who sat on the top rung of the masculinity ladder, interacted with his subordinates, both men and women of relatively lower status. As a matter of fact, although the point of departure for the present essay is the experiences of AfricanSouth African men, Uriah's subordinated masculinities may throw light on the lives of many a man, whose masculinities have been subordinated irrespective of their race and ethnicity both locally and globally. In 
the following section, we engage at length, the types of masculinities performed by ancient biblical personalities who were seemingly privileged by patriarchy. Bathsheba's husband, Uriah, will be discussed as an example in order to show that men whose masculinities have been subordinated, not only have a place on the hegemonic masculinity ladder; they also have a sense of agency.

\section{Reading Uriah's masculinities in $\mathbf{2}$ Samuel $\mathbf{1 1}$}

When one reads the David-Uriah narrative (2 Sam 11), three types of masculinities present themselves clearly: (1) hegemonic, (2) subordinate and (3) marginal masculinities (Connell 2005). First, Uriah's masculinity can be described as hegemonic. Although Uriah's position on the hegemonic masculinity ladder is lower than that of David, Uriah is the ba'al of his wife Bathsheba in a patriarchal context. In addition, Uriah is no ordinary man. $\mathrm{He}$ is one of the commanders in David's army. The latter feature becomes important for masculinist studies when we agree with Haddox (2016:176206) that military might is one of the features that typify ideal manhood cross-culturally.

Secondly, Uriah can also be viewed as performing subordinate masculinity. Like many male characters in the $\mathrm{HB}$, Uriah is portrayed as being heterosexual. However, his performance of masculinity in the text of 2 Samuel 11 reveals his relative subordinate status compared to that of David. As noted previously, though Uriah at some point resisted David's orders, his masculinity is still subordinated to that of a man with a higher social status.

Thirdly, Uriah's masculinity can also be described as marginal on account of his ethnicity. Unlike David, an Israelite king, Uriah was a Hittite man. Noteworthy is the fact that studies on masculinities and the $\mathrm{HB}$ are relatively recent (Haddox 2016:176-206). It is no wonder that marginal characters (e.g., Uriah), have basically received little or no attention from a masculinist studies perspective. ${ }^{5}$

5 Kopano Ratele's insights in this regard are helpful: "We have to stop treating men who are in reality marginalised by capitalist, white and black heteropatriarchal ideologies as if they have power. We cannot go on approaching and theorizing poor, poorly educated, young black men for example, as if they are the same as rich men. We need to look at 
In the present account though, informed by both the histories of racial inequities and of men with mostly subordinated masculinities, I find characters like Uriah appealing for the following three reasons.

First, Uriah is the "Other" in terms of his ethnicity within the Israelite context. Uriah, unlike David the Israelite, is a Hittite. Depicting this Otherness of characters who relatively sit at the bottom of the hegemonic masculinity ladder, the following remark is noteworthy: "Bathsheba herself does not matter, beyond David's desire for her. Uriah doesn't either. This Hittite is a leader in David's army, and he remains loyal even when he is drunk. Uriah's uncompromising sense of duty highlights a stark comparison: a drunken foreigner is a better man than the great King David." 6

Second, within the hegemonic masculinity ladder, Uriah's masculinities, like the masculinities of men in the Two Thirds majority world context, appear to be subordinated to David's masculinities. Perhaps it occasions no surprise that studies on HB masculinities, most of which are basically written by white males, have focussed more on David's character than on Uriah's character (cf. 2 Samuel 11).

Third, although Uriah's (hegemonic) masculinity appears to be subordinated to David, as a man in a patriarchal space, Uriah has power over Bathsheba, his wife. As one of the commanders in David's army, Uriah's hegemonic masculinity would have allowed him to give orders to the soldiers of a lower rank because hegemonic masculinity is not only a practice that gives room for men's dominance over women to continue; it is also a way of dominating males who fail to enact a hegemonic masculinity. In the case of Uriah, the social class issue rather than that of his sexual orientation would be relevant for the preceding argument (Mondaca 2016).

Cross-cultural studies have shown a number of typical features of hegemonic masculinity. Although such features are not equally significant or present in all patriarchal cultures, they represent common ways through which masculinity is performed in many social contexts. Haddox (2016:179-182)

our subjects in their proper and full context. Not doing this contributes to the failure to liberate men, perhaps we quite often do not really see them (2016:87).

6 Living by the Word, 2015. n.p. 
itemises these features as: military might, bodily integrity, honour, virility, provisioning and spatiality. Each of these features is discussed below.

\subsection{Military might}

The words of Dennis T. Olson regarding masculinity and violence are a fitting introduction to this sub-section: "The tendency for violence and revenge to spiral out of control among males - whether in families, gangs, communities, or nations - finds its first biblical expression here as Lamech pledges, "If Cain is avenged sevenfold, truly Lamech seventy-sevenfold (Gn 4:24; cf. v. 15)...This predominant (though not exclusive) link between masculinities and violence has marked human experience throughout its history with disastrous results, ranging from domestic violence to world wars."(2006:83) So, the centrality of physical strength to biblical hegemonic masculinity is linked to violence.(cf Wilson 2019: 24)

Haddox argues that one of the most common characteristics of masculinity cross-culturally is valour in warfare. War has basically been men's domain and "a literal field for contesting masculinity" (Haddox 2016:180). Thus, David J. Clines could argue that: "Being able to fight and to kill lots of other men is ideal in an ancient Israelite society; it is characteristic of what men do, and it is a sign of their masculinity" (2013:215-228). The element of honour, as one of the features of masculinity cross-culturally (cf here below) may be linked to the one on the military might. How so? A man could gain honour through sexual competition (cf the case of the women who gets raped and/or are taken as captives in specific war contexts. The example of Absalom having sex publicly with his fathers' concubines can also be cited as a case in point here ;Wilson2019: 27).

The opening verse of the text of 2 Sam 11, throws some light on the military might of David's men. Uriah was among David's troops. Out of loyalty to a more powerful man, to a foreign nation and/ or commitment to being a breadwinner within the patriarchal household, Uriah, the Hittite, joined the ranks of David's warriors. The fact that Uriah belonged to one of David's warriors and a trusted one (cf. his being stationed in the frontline of the battle though the real motive behind the move is known to present day readers of his story) reveals something of his military capabilities. His commitment not only to the political health of the Israelite nation but to the course of Israel's deity, was revealed by his refusal to the king's exhortation 
to him to go to his house (2 Sam 11:11). Drawing my argument closer to home, during the period of apartheid in South Africa, Uriah might have been criticised as a sell-out for continuing to serve the interests of the "Empire" in an attempt to earn an income and a living. One would further argue that David and the other Israelites were fighting for the land that was originally not theirs; the land that was being claimed in the name of the deity (cf. 2 Sam 10:12). For example, during the apartheid era, many South African men went into exile in their struggle to regain both their land and the freedom of their people. In so doing, many of them left their wives and children back home. Mothers and children had to endure periods in years with an absentee husband and father. Some men never came back alive. Uriah had to pledge allegiance with a non-Hittite yet more powerful male person, David. However, the latter's actions revealed that "allegiance" would come second to killing, presupposing that by so doing he would obscure evidence of him sleeping with Bathsheba, Uriah's wife. Joab had to obey David's orders of stationing Uriah where the battle was fierce (2 Sam 16) because King David had wanted Uriah dead.

\subsection{Bodily integrity}

One's inability to defend oneself from bodily penetration as a man (be it by warfare weapons, corporal punishment or sexual penetration) compromised one's masculinity. We may assume that as one of the commanders in David's army, Uriah would have passed the preceding test prior to a deliberate plan by a man who sat on a higher rung of the masculinity ladder to have Uriah's fatal military penetration. As a heterosexual man, Uriah would have penetrated the one whose feminine sex would have legitimised such without attracting any shame on his wife's part. However, his subordinate masculinity is revealed in his absence because David had the audacity to penetrate Uriah's "property" (2 Sam 11: 4). In the preceding case, Uriah failed as a man to protect his wife (read: property) including his territory for sexual intimacy as a heterosexual married man. However, neither sexual hospitality nor adultery were tolerated during this time of Israel' s history. The reaction of the prophet Nathan against what David did (cf 1 Sam 12) makes sense in the light of the preceding observation as adultery was regarded as a serious offence against the authority of the man whose property would have been violated (cf Dreyer 2012:24). 


\subsection{Honour}

$[\mathrm{H}]$ onour is a value embodied by adult males. Hence, both Wikan (1984:635-652) and Clines (2013:215-228) express the idea that honour is intricately tied up with male ideology. When the concept of "honour" is applied to the analysis of masculinity in biblical studies, particular focus has been on a man's ability to show control of the sexuality of women in his household, that is, daughters and wives (Haddox 2016:180-181). In the view of Ken Stone though, the honour gained by a specific man happens in the context of sexual competition on the wife of a rival as in the case of the scandal done by Absalom on the concubines of his father. In the latter case, a man competes against a fellow man while in the preceding case, a man retains his honour by his ability to control the sexuality of females in his household. In this regard, Dreyer rightfully argues: "Women's 'exclusivity' was defended by the males. Male honour was symbolised by the testes. The role of the father was to exercise authority over the family and defend its honour" (2012:21). From a gender-sensitive perspective, what is worth noting though is that irrespective of the "object" which is being used to preserve male honour and prestige, one who usually receives the short end of the stick is one whose power patriarchy does not legitimate, that is, a woman.

According to the preceding model, male honour mainly depends on the shame, that is, the chastity of women in men's households. In light of what was discussed in the preceding aspect of "bodily integrity", Uriah's honour as a man cannot be sustained as he was not present to protect the chastity of his wife. The argument in favour of Bathsheba willingly yielding to David's sexual advances (Bailey 1990:88) may even enhance the level of the shame to be cast on the masculinity of Uriah because it may cast doubt on the strength of Uriah's virility.

\subsection{Virility}

Virility entails sexual prowess. An ideal Israelite man was supposed to be able to have children, especially sons. Argues Wilson: “... fertility and the virile production of children contribute significantly to the portrait of idealized hegemonic masculinity in the HB"(2019:27). However, linking this element of virility with the one on self-control, Wilson reminds us that the aim of virility as a sign of biblical manhood then was not to randomly 
father many children (contra what David does in the present episode), but to father legitimate children by legitimate wives (2019: 27). The preceding aspect cannot be handled with some precision from the text (2 Sam11) because Uriah's household is depicted as a husband-less one. Uriah's narrative basically features as an appendage to the narrative of the "real" hegemonic man, that is the Israelite king, David. Noteworthy though, is the fact that there are commentators who do not read rape in the encounter between David and Bathsheba. The latter is viewed as having deliberately seduced David and willingly went to him. If the preceding argument holds waters, it may be argued that Uriah may not have satisfied Bathsheba sexually, an assumption that would put Uriah's virility in doubt. We may also question Uriah's refusal to go and have intimacy with his wife when granted such a "precious" opportunity by the king. May that be an overt revelation of Uriah's weak virility? Uriah's response though, reveals that on this aspect, his masculinity was subordinate not to a fellow (male) human being, but to God.

\subsection{Provisioning}

As in any patriarchal ${ }^{7}$ community/context, the family in ancient Israel consisted of a man, who was not only its head, but also its founder. As the founder, the man would be the one who takes a wife in marriage and also becomes her ba'al, master. The house was indeed the house of one's father (cf beth 'ab). The family head was responsible for the provisions and protection of all who belonged to his household (De Vaux 1973:20). A man's ability to provide for his own household was one other component of masculinity in ancient Israel. If provisions were not enough, a leeway could be given for women to stray and consequently add to the dishonour which the man suffered (see Haddox 2016:181; Clines 2013:215-228). In her book on masculinity and honour in Hosea (2011), Haddox shows that a man's provision for as well as protection for his family was also connected

7 Douglas A. Knight brings in an interesting dynamic of an egalitarianism of some sort in the parties contribution to the family economy, especially in the village setting. He reasons: "On the whole, it is safe to assume that a patriarchal system prevailed in village society as it did in urban contexts, but probably without the same stringency since all parties in a subsistence economy needed to contribute as much as possible to their mutual continuation" (2011:132). 
to his honour. (cf the references to providing grain, wine and oil as they are reflected in Hos. 2: 5, 8, 22).

At face value, an absentee father like Uriah could be viewed as one who cared less about the welfare of his household. However, the very fact of Uriah's absence from his house should be construed as a sign of his commitment not only to the Israelite deity, but also to his own family. Even with the preceding component of Uriah's masculinity, the subordinate element becomes notable. His masculinity gets subordinated because as already noted, Uriah goes to war by the orders of a man who sits relatively on the upper rungs of the hegemonic masculinity ladder.

\subsection{Spatiality}

The element of spatiality deals with the gendered spaces which were traditionally allocated to men and women, that is, the public space being traditionally allocated to men while the private space was and still is basically allocated to women. Rosaldo provides a useful description of the differences between the preceding two domains, that is the public and the private spheres. The word 'domestic' refers to the minimal institutions and the modes of activity organised immediately around one or more mothers and their children, while 'public' refers to activities, institutions and forms of association which connect, rank, organise or sub-subsume specific mother-child groups. In her view, the preceding organisation provides a universal framework for conceptualising the activities of the sexes (Rosaldo 1974:23).

As politics, large-scale economics and communal religious rituals usually happen in the public sphere, men have dominant conspicuous power in communities. Men are thus "...expected to spend most of their time and energy in the public realm, and those who too often frequent the private realm are ridiculed as behaving like women" (Haddox 2016:182).

Likewise, the space occupied by Uriah in the present episode is a public male sphere of war. Bathsheba remains within the private space of the household. Could it be that Bathsheba's daring move to "transgress" the designated "spatial" boundaries is the one that impelled her into trouble? The "transgression" coxed her to the violation of her body by a man who, 
though was supposed to have integrated with other men within the public male military space, chose not to do so.

In this section, an attempt was made to explore Uriah's performance of his masculinities in relation to David and Bathsheba. In the next section, the conversation alternates to another level by exploring women's place within hegemonic masculinities.

\section{Wo(men)'s place within hegemonic masculinities}

Power enables those who possess it to both build and to destroy. Legitimated power enables its possessors to do whatever they deem fit irrespective of its repercussions on fellow human beings. From our reading of the David/ Uriah/Bathsheba narrative above, those who possess power tend to be inward-looking, self-serving and greedy while those human beings who sit at the bottom of the ladder are usually interrogated and humiliated. In the case of the hegemonic masculinities ladder, women and men who are "Othered" by their sexual orientation among others are usually found at the bottom of the ladder. As a woman in a patriarchal context, Bathsheba suffers both victimization and humiliation. She gets trapped in the power dynamics between a more powerful man and a less powerful man who was however her ba'al. Her female body (read:femininity) in a hetero-patriarchal space makes her the most victimized character among the three characters engaged within the narrative. Within such a space, beautiful female bodies (irrespective of their marital statuses) can be violated with ease by powerful men. If Bathsheba were a handsome man (Clines 2013:221-223), would David have ordered him to be brought forward to him?

In our contemporary context, the Bathsheba character represents (South) African women in many ways. For example, on account of the harsh migrant labour policies, women had to do the tasks of both father and mother (a temporary "widow"?) in the absence of a husband who had to depart (was sent out) to do male business for the welfare of both his family and the nation. The taxing exercise of waiting in such spaces was done by those who sat at the very bottom of the hegemonic masculinities ladder, the women. 
When Uriah, the less-powerful man was recalled from the battlefield by the king and exhorted to re-unite with his family but refused, some readers, including the narrator of the story, may applaud Uriah for defying the king's order. However, who became the victim(s) in the process? Bathsheba and her children, it may be argued. Uriah's defiance of a command by a more powerful male person reminds us that the "powerless" has a sense of agency.

\section{The agency of "powerless" women and men}

Are the powerless without power at all? Or they have power, though it may not be legitimated? A woman's everyday life experiences in a patriarchal world presuppose that those on the margins have a sense of agency. For example, one would argue that Bathsheba was not powerless. The very fact that she could convey a message to the king informing him about the pregnancy suggests that she was not powerless. The observation that she could mourn the death of her husband reveals some measure of agency in her life. Although their power may not be legitimated by heteropatriarchy or hegemonic masculinities, powerless women have the capacity to navigate life with success even as they have the capacity to defy, either covertly or overtly, those who are more powerful than they are. Although the portrait given by Steve Biko (1996[1978]) about black men in apartheid South Africa may persuade us to think otherwise, Black men (including black women, back then and now) were/are not totally devoid of power. The above assertion is supported by the very fact that the political resolve and revolutionary consciousness of the oppressed were motivated by their determination to fight for the liberation of the marginalised Black people. The act of "waiting" on the part of Black women and the act of "playing" both roles of father and mother in the absence of their men, point to the power of agency.

Uriah, the less-powerful man in the narrative, serves as another example in this regard. Although his masculinity was effectively subordinated when he was ordered by the king to leave a war setting, Uriah used his agency to thwart the completion of the king's full agenda. Given our human tendencies to always aspire for comfortable lives, it does not make sense for a male human being to refuse a prerogative to come home and enjoy the comfort 
and pleasure of being with his wife. Perhaps Uriah had been informed by fellow men (or colleagues in the army, including the king's servants with whom he chose to spend the night) that his wife was summoned to the king in his absence. Although the narrator of Uriah's story leaves the preceding questions unanswered, he however, points us to what seems to be a critical aspect of biblical masculinities, that is, a masculinity subordinated not to any human being irrespective of his social status, but one subordinated to God.

\section{Concluding remarks}

In this essay, an attempt was made to engage the concept of hegemonic masculinities as they are performed by David and Uriah in the text of 2 Sam11. Some features of hegemonic masculinities present themselves in varying degrees in the text. David who sits on the top of the hegemonic masculinities ladder is able to exercise his power over men and women, including the wife of another man. Although the character of Uriah was presented as being subordinated to David, the king, as a man in a patriarchal context, and as one of the commanders in David's army, Uriah also benefitted from his location on the hegemonic masculinity ladder. Although Uriah's masculinity is subordinated to that of a man with a higher status than himself, he still had a sense of agency, in that way, he can serve as a model to numerous other men who sit in subordinated positions on the hegemonic masculinity ladder.

Even more importantly in my view, is the kind of masculinity that is depicted as being subordinated to God?

Haddox (2016:13-14) argues for what others, especially those of us located in the global South, may regard as liberating notions of masculinity. According to Haddox (2016), biblical masculinity is viewed in relation to the favour that God bestows on a specific man irrespective of his flaws. She reasons, "Perhaps the most useful lesson that we can learn for our own context is that biblical masculinity is not about demonstrating constant supremacy and never showing weakness, as masculinity is often understood today. At times biblical men take the dominant role, but sometimes they defer to others, including their wives, and always to God, if they are successful" (Haddox 2016:13-14). 
From the language of Uriah's blunt refusal (2 Sam 11:11 MEV) to go and enjoy the comfort of his home at the exhortation of the king, it is clear that he chose to defer to God. What comes to mind here are the words of Moshe Garsiel about the successes of kings in battle: "Throughout the book of Samuel, success in battle is viewed as a function of the king's conduct and not as a value in itself" (1993:250). Uriah chose to submit to what he believed to be the will of God for the nation at that point in time, that is to be in a messy, uncomfortable space on behalf of God and of God's people than to do what the king advised/exhorted him to do. The favour of God is found with such men. Thus, Haddox (2016:13) reasons: “... if a man fulfils all of the categories of masculinity expected by society, such as honour, potency, and wisdom, but does not submit to God, he will not be favoured by God".

In that sense, the preceding aspect of the individual agency of the powerless becomes visible even here. Powerful (male) human beings may be enabled to know that there is an un-gendered power (although almost always portrayed as male in the $\mathrm{HB}$ ) whose delight is on all human beings irrespective of their position in the society's hegemonic masculinities" ladder. Choosing the path of defiance, choosing to defy the powerful of this earth even or precisely on account of the choice to defer to the Sacred Other, usually comes with its own costs. Those who dare to defy powerful men, may end up carrying their own death warrants, just as Uriah did! It is clear then, that the struggle for the affirmation of all men, including those who sit at the bottom of the hegemonic masculinities ladder continues.

\section{List of references}

Abasili, AI 2011. "Was it Rape? The David and Bathsheba Episode ReExamined". Vetus Testamentum 61:1-15.

Bailey, RC 1990. David in Love and War. JSOTSup, 75: Sheffield.

Baloyi, EM 2013. "Critical Reflections on Polygamy in the African Christian Context”. Missionalia 41/2:164-181.

Biko, S 1996 [1978]. I Write What I Like. Johannesburg: Ravan Press. 
Boer, R 2011. “The Patriarch's Nuts: Concerning the Testicular Logic of Biblical Hebrew". Journal of Men, Masculinities and Spirituality 5(2):41-52.

Clines, DJA 1995. Interested Parties: The Ideology of Writers and the Readers of the Hebrew Bible. Sheffield: Sheffield Academic Press.

Clines, DJA 2013. Play the Man! The Masculine Imperative in the Bible. Sheffield: Sheffield Phoenix.

Connell, R 2005. Masculinities. Berkeley, CA: University of California Press.

Creanga, O 2019. Hebrew Masculinities Anew. Sheffield Phoenix Press: Sheffield.

De Vaux, R 1973. Ancient Israel: Its life and Institutions. Darton, Longman \& Todd Ltd: London.

Dreyer, Y 2012. "Sexuality and shifting paradigms-setting the scene".

In: Study guide 1 for OTS3704. Edited by Eben Scheffler and Masenya(Ngwan’a Mphahlele), Unisa, Pretoria. 18-36.

Fewell, DN and Gunn, DM 1993.Gender, Power and Promise: The Subject of the Bible's First Story. Nashville: Abingdon.

Freymeyer, RH 1997. "Rape Myths and Religiosity”. Sociological Spectrum 17(4):473.

Garland, DR and Garland, DE 2007. Flawed Families of the Bible: How God works through Imperfect Relationships, Family and Community Ministries. Bathsheba's story: Surviving abuse and loss. Grand Rapids: Brazos Press.

Garsiel, M 1993. “The Story of David: A Different Approach”. The Catholic Biblical Quarterly 55:244-263.

Genrich, D 2011. "Men and Masculinities in South Africa: Essays and Perspectives". PACSA and Sonke Gender Justice Network. [Online]. Available: pacsa.org.za/images/docs/men_and_masculinities_in_ south_africa_volume_2.pdf [Accessed: 12 July 2019]. 
George, M K 2010. "Masculinity and its Regimentation". In: Men and Masculinity in the Hebrew Bible and beyond, edited by Ovidiu Creanga. BMW 33 Sheffield: Sheffield Phoenix. 64-82.

Gqola, PD 2013. Rape: A South African Nightmare. Johannesburg, Aukland Park: MFBooks.

Gray, NB, Palileo, GJ and Johnson, DG 1993. "Explaining Rape Victim Blame: A Test of Attribution Theory". Sociological Spectrum 13:377392.

Hackett, J O 2012. “1 and 2 Samuel”. In: Women's Bible Commentary, Twentieth Anniversary Edition. Edited by Carol A. Newsom, Sharon H. Ringe and Jacqueline E. Lapsley. Louisville, KY: WJK-Westminster John Knox Press. 150-163.

Haddox S E. 2011. Metaphor and Masculinity in Hosea. Studies in Biblical Literature. 141. New York: Peter Lang. 141

Haddox, SE 2016. "Is There a Biblical Masculinity? Masculinities in the Hebrew Bible". World and Word 36(1):5-14.

Haddox, SE 2016. "Masculinities Studies of the Hebrew Bible: The First Two Decades". Currents in Biblical Research 14(2):176-206.

Knight, D A 2011. Law, Power and justice in Ancient Israel. Louisville, KY: Westminster John Knox Press.

Leshota, P 2012. "Under the Spell of Discrete Islands of Consciousness: My Journey with Masculinities in the Context of HIV and Aids". In: Redemptive Masculinities: Men, HIV and Religion, edited by Ezra Chitando and Sophie Chirongoma. Geneva: WCC. 147-170.

Living by the Word, 2015. "17th Sunday in Ordinary Time 2 Samuel 11:1-15”. Christian Century July 22: n.p.

Masenya (Ngwan'a Mphahlele), M 2017. “Towards an MIT-Conscious Biblical Studies in South Africa? Glimpsing the Stories of Absent Husbands and Waiting Wives". Old Testament Essays 30(2):384-402.

Mondaca, NT 2016. “A man after God's own Heart: Biblical, Hegemonic and Toxic Masculinities in As Meat Loves Salt". Unpublished BA Dissertation. Stockholm: Stockholm University. 
Morrell, RM 1998. "Of Boys and Men: Masculinity and Gender in Southern African Studies”. JSAF 24(4):605-630.

Murphy, KJ 2015. "Masculinity, Moral Agency, and Memory: The Spirit of the Deity in Judges, Samuel, and Beyond". J Bible Recept 2(2):175-196.

Ndebele, N 2008. The Cry of Winnie Mandela. Claremont: David Philip.

Olson D T 2006. "Untying the knot? Masculinity, Violence and the Creation-Fall Story of Genesis 2-4". In: Engaging the Bible in a Gendered World: An Introduction to Feminist Biblical Interpretation in Honor of Katharine Doob Sakenfeld. Edited by Linda Day and Carolyn Pressler, Westminster John Knox Press: Louisville, London. 73-86.

Ratele, K 2016. Liberating Masculinities. Cape Town: HSRC.

Rosaldo, M. Z. 1974. "Woman, culture and society: A theoretical overview" In: Women, Culture and Society. Edited by M. Z. Rosaldo and L. Lamphere. Stanford: Stanford University. 17-42.

Wilson,S M 2019. "Biblical masculinity studies and multiple masculinities theory: past, present, and future". In: Hebrew Masculinities Anew. Edited by Ovidiu Creanga. Sheffield Phoenix Press: Sheffield. 19-40.

Swartz, RM 1998. "Adultery in the House of David: The Metanarrative of Biblical Scholarship and the Narratives of the Bible". In: Woman in the Hebrew Bible, edited by Alice Bach. New York: Routledge. 346.

Thobejane, TD and Takayindisa, F 2014. "An Exploration of Polygamous Marriages: A Worldview”. Mediterranean Journal of Social Sciences 5/27:1058-1066.

Youngblood, RF 1994. “1 and 2 Samuel”. In: Zondervan NIV Bible Commentary: An Abridgement of the Expositor's Bible Commentary, Volume 1: Old Testament, edited by Kenneth L. Barker and John R. Kohlenberger. Grand Rapids, Michigan: Zondervan Publishing House. 378-486.

Wikan, U 1984. "Shame and Honour: A Contestable Pair". Man 19:635652. 